\title{
LANDASAN FILOSOFIS DAN ASAS-ASAS \\ DALAM HUKUM PENANAMAN MODAL DI INDONESIA
}

\author{
Ardiana Hidayah \\ Fakultas Hukum Universitas Palembang \\ Email: ardyanah@yahoo.co.id
}

\begin{abstract}
Pancasila as the philosophical foundation of the Indonesian nation which contains noble ideals and guidelines in the life of the nation and state in running the economy in Indonesia. This also influences economic development through investment activities. Investment arrangements in Indonesia are regulated in Law Number 25 of 2007 concerning Investment, that investment is carried out on the basis of: legal certainty; openness; accountability; equal treatment and does not differentiate national origin; togetherness; fair efficiency; sustainable; environmentally sound; independence; balance of progress and unity of the national economy.
\end{abstract}

Keywords: Philosophical Basis; Investment Principle

\section{Abstrak}

Pancasila sebagai landasan filosofis bangsa Indonesia yang mengandung cita-cita luhur dan pedoman dalam kehidupan berbangsa dan bernegara dalam menjalankan perekonomian di Indonesia. Hal tersebut juga berpengaruh dalam pembangunan perekonomian melalui kegiatan penanaman modal. Pengaturan penanaman modal di Indonesia diatur dalam Undang-Undang Nomor 25 Tahun 2007 tentang Penanaman Modal, bahwa penanaman modal diselenggarakan berdasarkan asas: kepastian hukum; keterbukaan; akuntabilitas; perlakuan yang sama dan tidak membedakan asal negara; kebersamaan; efesiensi berkeadilan; berkelanjutan; berwawasan lingkungan; kemandirian; keseimbangan kemajuan dan kesatuan ekonomi nasional.

Kata Kunci: Landasan Filosofis; Asas Penanaman Modal

\section{PENDAhULUAN}

Pembentukan pemerintahan negara salah satunya bertujuan untuk memajukan kesejahteraan umum. Amanat tersebut, antara lain, telah dijabarkan dalam Pasal 33 UndangUndang Dasar Negara Republik Indonesia Tahun 1945 dan merupakan amanat konstitusi yang mendasari pembentukan seluruh peraturan perundang-undangan di bidang perekonomian. Konstitusi mengamanatkan agar pembangunan ekonomi nasional harus berdasarkan prinsip demokrasi yang mampu menciptakan terwujudnya kedaulatan ekonomi Indonesia. Keterkaitan pembangunan ekonomi dengan pelaku ekonomi kerakyatan dimantapkan lagi dengan Ketetapan Majelis Permusyawaratan Rakyat Republik Indonesia Nomor XVI/MPR/1998 tentang Politik Ekonomi Dalam Rangka Demokrasi Ekonomi sebagai sumber hukum materiil. Dengan demikian, pengembangan penanaman modal bagi usaha mikro, kecil, menengah, dan koperasi menjadi bagian dari kebijakan dasar penanaman modal.

Berkaitan dengan hal tersebut, penanaman modal harus menjadi bagian dari penyelenggaraan perekonomian nasional dan ditempatkan sebagai upaya untuk meningkatkan pertumbuhan ekonomi nasional, menciptakan lapangan kerja, meningkatkan pembangunan ekonomi berkelanjutan, meningkatkan kapasitas dan kemampuan teknologi nasional, mendorong pembangunan ekonomi kerakyatan, serta mewujudkan kesejahteraan masyarakat dalam suatu 
sistem perekonomian yang berdaya saing.

Pengaturan penanaman modal berdasarkan pada sistem ekonomi Indonesia yang diramu dalam konsep sistem ekonomi nasional secara jelas disebutkan dalam Pasal 33 ayat 4 UUD 1945, yakni "Perekonomian nasional diselenggarakan berdasarkan demokrasi ekonomi dengan prinsip kebersamaan, efesiensi berkeadilan, berkelanjutan, berwawasan lingkungan, kemadirian, serta dengan menjaga keseimbangan kemajuan dan kesatuan ekonomi nasional."

Pembangunan ekonomi di Indonesia melalui kegiatan penanaman modal secara kajian filosofis dan pemahaman terhadap asas-asasnya harus berdasarkan sistem ekonomi Indonesia yang berdasarkan Pancasila dan UUD 1945, yakni perekonomian di Indonesia dilakukan dalam rangka mewujudkan keadilan sosial bagi seluruh rakyat Indonesia (social justice, fairness, equity, equality).

\section{A. PERMASALAHAN}

Oleh karena itu, penulisan mengangkat masalah apa yang menjadi landasan filosofis dalam Hukum Penanaman Modal di Indonesia, serta bagaimana penjelasan terkait asas-asas dalam Hukum Penanaman Modal di Indonesia.

\section{PEMBAHASAN}

\section{Landasan Filosofis Hukum di Indonesia}

Telaah Filsafat pada suatu objek bersandar pada tiga hal, yakni: ontologi, epistimologi dan aksiologi. Epistemologi berupaya mencari kebenaran yang dibangun dengan logika dan didahului oleh uji konfirmasi tentang data yang terhimpun. ${ }^{1}$ Kebenaran yang ada (the being) menjadi masalah ontologi yang objeknya adalah hakekat realitas, sedangkan aksiologi merupakan kebenaran (the right).

Objek kajian filsafat mencakup bidang yang sangat luas, yakni hasil atau produk ilmu, pengalaman di bidang keagamaan, etika, logika, estetika, ideologi dan teknologi. Filsafat hanya melihat objek dari sudut tertentu yakni dari sudut keumumannya, sedangkan sudut kekhususan termasuk ruang lingkup ilmu. ${ }^{2}$

Ilmu hukum sebagai ilmu preskriptif yakni mengatur ilmu bagaimana seharusnya manusia bertindak. ${ }^{3}$ Hukum diciptakan manusia agar dapat tercapai kehidupan yang adil, damai sejahtera dan maju. Hukum merupakan alat manusia dalam mencapai tujuan yang telah ditetapkan masyarakat.

Hukum yang dirumuskan dalam undang-undang merupakan hukum dalam norma atau kaedah yang didalamnya memuat sesuatu yang dicita-citakan, sebaliknya hukum adat merupakan bentuk kebiasaan yang hidup dalam masyarakat merupakan kenyataan atau realitas hukum. Norma hukum ${ }^{4}$ merupakan aturan yang bersifat mengikat kepada setiap

\footnotetext{
1 Noeng Muhadjir, Filsafat Ilmu, Yogyakarta: Rake Sarasin, 2015, hlm.77

${ }^{2}$ Indah Febrian, Aspek Filosofis dalam Hukum Ekonomi, Simbur Cahaya No. 43 Tahun XV, September 2010, hlm. 2182.

3 Peter Machmud Marzuki, Penelitian Hukum, Jakarta: Kencana Prenada Media Group, 2009, hlm. 28.
}

4 Elsi Kartika Sari dan Advendi Simanunsong, Hukum dalam Ekonomi, Jakarta: PT Gramedia Widiasarana Indonesia, 2008, hlm. 2 
orang yang pelaksanaanya dapat dipertahankan dengan segala paksaan oleh alat-alat negara untuk melindungi kepentingan manusia dalam pergaulan masyarakat.

Landasan filosofis hukum merupakan pertimbangan atau alasan yang menggambarkan bahwa peraturan yang dibentuk mempertimbangkan pandangan hidup, kesadaran, dan cita hukum yang meliputi suasana kebatinan serta falsafah bangsa Indonesia yang bersumber dari Pancasila dan Pembukaan Undang-Undang Dasar Negara Republik Indonesia Tahun 1945.

Gagasan Bung Karno tentang Pancasila merupakan filsafat sosial yang hebat. Cita Ketuhanan Yang Maha Esa tahun 1945 menjadi pengakuan pluralisme agama, Perikemanusiaan dan Keadilan Sosial sesuai dengan Welfare liberalism dari Rawl, Persatuan Nasional sebgai jabaran Bhinneka dalam budaya dan Tunggal Ika dalam politik. ${ }^{5}$ Sehingga kajian dalam Filsafat Pancasila digolongkan menjadi dua, yaitu falsafah Pancasila bersifat religious dan falsafah pancasila dalam arti praktis. Falsafah Pancasila bersifat religious, artinya filsafat pancasila mengenal adanya kebenaran mutlak yang berasal dari Tuhan Yang Maha Esa, sekaligus mengakui keterbatasan kemampuan manusia. Sedangkan falsafah pancasila dalam arti praktis, digunakan sebagai pedoman hidup sehari-hari, agar hidupnya dapat mencapai kebahagiaan lahir dan batin, baik dunia maupun akhirat.

${ }^{5}$ Noeng Muhadjir, Filsafat Ilmu, Op.Cit,
Pancasila memiliki tiga fungsi pokok yakni: falsafah Pancasila sebagai pandangan hidup bangsa; falsafah Pancasila sebagai dasar negara; dan falsafah Pancasila sebagai jiwa dan kepribadian bangsa Indonesia.

$$
\text { a. Falsafah Pancasila }
$$

sebagai pandangan hidup bangsa digunakan sebagai pegangan, pedoman atau petunjuk oleh bangsa Indonesia dalam kehidupan sehari-hari. Pancasila juga digunakan sebagai pedoman dalam memecahkan masalah di dalam negeri seperti politik, ekonomi, sosial dan budaya. Tanpa memiliki pandangan hidup maka bangsa Indonesia akan terombang-ambing dalam menghadapi persoalan yang pasti akan timbul, baik persoalan di dalam masyarakatnya sendiri, maupun persoalan dari bangsabangsa di dunia.

$$
\text { b. Falsafah Pancasila }
$$
sebagai dasar Negara Republik Indonesia, yakni sebagai dasar Negara harus kokoh dan kuat agar Indonesia tetap berdiri tegak dan juga harus tahan uji terhadap serangan-serangan baik secara internal maupun eksternal. Oleh karena itu seluruh peraturan perundang-undangan Republik Indonesia harus sejiwa dan sejalan dengan Pancasila. Dan telah ditegaskan bahwa Pancasila adalah sumber dari segala sumber hukum yang ada di negara Republik Indonesia.

$$
\text { c. Falsafah Pancasila }
$$

sebagai jiwa dan kepribadian bangsa Indonesia, Pancasila memberikan corak yang khas kepada bangsa Indonesia dan tak dapat dipisahkan dari bangsa Indonesia, serta merupakan ciri khas yang dapat membedakan 
bangsa Indonesia dari bangsa yang lain. Walaupun bangsa Indonesia sejak dahulu bergaul dengan peradaban kebudayaan bangsa lain dan saat ini dipengaruhi unsurunsur asing, namun kepribadian Indonesia tetap hidup dalam kepribadiannya sendiri. Dan kelima sila dari Pancasila merupakan satu kesatuan yang tidak terpisahkan, yang menjadi ciri khas bangsa Indonesia.

Pancasila sebagai pandangan hidup bangsa Indonesia dapat dipahami dalam makna nilai, norma, etika dan moral. Nilai sebagai kualitas yang melekat pada subjek tertentu yang berakibat dipilih atau tidaknya subjek tersebut dalam kehidupan masyarakat. Pemerintahan yang adil menjadi dambaan dan keinginan bersama bagi rakyat. Apabila nilai tersebut terwujud maka akan bermuara pada rasa tentram, nyaman, sejahtera dan bahagia.

Nilai adalah kualitas bagi kehidupan manusia, masyarakat, bangsa dan antar bangsa. Maka nilai yang terdapat dalam Pancasila menjadi tujuan hidup bangsa Indonesia dan ingin diwijudkan dalam kehidupan bermasyarakat, berbangsa dan bernegara. Nilai yang terkandung dalam Pancasila dapat berupa damai, iman, takwa, adil, setara, selaras, serasi, rukun, mufakat, bijaksana, sejahtera dan sebagainya. ${ }^{6}$

Norma merupakan nilai dipergunakan sebagai ukuran dalam menentukan nilai suatu tingkah laku manusia. Dalam kehidupan bermasyarakat, berbangsa dan bernegara di

${ }^{6}$ Soeprapto, Pancasila, Jakarta: Konstitusi Press, 2013, hlm. 59.
Indonesia dikenal pada beberapa norma, yakni norma agama, norma moral, norma adat dan norma hukum. Dari beberapa norma tersebut maka norma hukum memiliki hak untuk memaksa, norma yang implementasinya bersendi pada kesadaran masyarakat bersangkutan.

Sedangkan etika sebagai cabang dari filsafat merupakan seperangkat nilai, prinsip dan norma moral yang selayaknya dikerjakan dan selayaknya dihindari.

Etika kehidupan berbangsa diatur dalam Ketetapan MPR RI Nomor: VI/MPR/2001. Rumusan tentang etika kehidupan berbangsa dirumuskan dengan tujuan menjadi acuan dasar untuk meningkatkan kualitas masyarakatnya dan kepribadian Indonesia dalam kehidupan berbangsa. meliputi: ${ }^{8}$

Etika kehidupan berbangsa

a. Etika Sosial dan Budaya bertolak dari rasa kemanusiaan yang mendalam dengan menampilkan sikap kejujuran, saling peduli, saling memahami, saling menghargai, saling mencintai dan saling menolong di antara sesama manusia dan warga bangsa serta perlu menumbuhkembangkan budaya malu, budaya keteladanan oleh para pemimpin formal maupun informal.

b. Etika Politik dan Pemerintahan dimaksudkan untuk mewujudkan pemerintahan yang bersih, efisien dan efektif serta menumbuhkan suasana politik yang demokratis bercirikan keterbukaan, rasa bertanggung jawab, tanggap akan aspirasi

\footnotetext{
${ }^{7} \mathrm{Ibid}, \mathrm{hlm} .60$
}

${ }^{8}$ Ibid, hlm. 61-63 
rakyat, menghargai perbedaan, jujur dalam persaingan serta menjunjung tinggi hak asasi manusia dan keseimbangan hak dan kewajiban dalam kehidupan berbangsa.

c. Etika Ekonomi dan Bisnis dimaksudkan agar prinsip dan perilaku ekonomi dan bisnis dapat melahirkan kondisi dan realitas ekonomi yang bercirikan persaingan yang jujur, berkeadilan, mendorong berkembangnya etos kerja ekonomi, daya tahan ekonomi, pemberdayaan ekonomi yang berpihak kepada rakyat kecil secara berkesinambungan. Etika ini untuk mencegah terjadinya praktek monopoli, oligopoli, kebijakan ekonomi yang mengarah kepada korupsi, kolusi, nepotisme dan diskriminasi.

\section{d. Etika Penegakan Hukum}

yang Berkeadilan dimaksudkan untuk menumbuhkan kesadaran bahwa tertib sosial, ketenangan dan keteraturan hidup bersama hanya dapat mewujudkan dengan ketaatan terhadap hukum dan semua peraturan yang berlaku. Etika ini meniscayakan penegakan hukum secara adil, perlakuan yang sama dan tidak diskriminatif terhadap setiap warganegara di hadapan hukum.

e. Etika Keilmuan
dimaksudkan menjunjung tinggi
nilai-nilai kemanusiaan, ilmu
pengetahuan dan teknologi agar
warga bangsa mampu menjaga
harkat dan martabatnya yang
berpihak kepada kebenaran untuk
mencapai kemaslahatan dan
kemajuan sesuai dengan nilai-nilai
agama dan budaya. Etika ini
diwujudkan secara pribadi ataupun
kolektif dalam karsa, cipta dan
karya yang tercermin dalam

perilaku kreatif, inovatif, inventif dan komunikatif dalam kegiatan membaca, belajar, meneliti, menulis, berkarya serta menciptakan iklim kondusif bagi pengembangan ilmu pengetahuan dan teknologi. Etika ini menegaskan pentingnya budaya kerja keras dengan menghargai dan memanfaatkan waktu, disiplin dalam berpikir, berbuat dan menepati janji serta mendorong tumbuhnya kemampuan menghadapi hambatan, rintangan dan tantangan dalam kehidupan, tahan uji dan pantang menyerah.

f. Etika Lingkungan menegaskan pentingnya kesadaran menghargai dan melestarikan lingkungan hidup serta penataan tata ruang secara berkelanjutan dan bertanggung jawab.

2. Landasan Filosofis Hukum Penanaman Modal di
Indonesia

Pancasila sebagai landasan filosofis bangsa Indonesia yang mengandung cita-cita luhur dan pedoman dalam kehidupan berbangsa dan bernegara dalam menjalankan perekonomian bangsa Indonesia. Cita-cita bangsa Indonesia sebagaimana termaktub dalam Pembukaan Undang-Undang Dasar Negara Republik Indonesia Tahun 1945 menyatakan bahwa salah satu tujuan bangsa Indonesia adalah untuk mewujudkan kesejahteraan umum bagi seluruh rakyat Indonesia. Sebagaimana diamanatkan dalam Pasal 33 UUD 1945 bahwa Perekonomian disusun sebagai usaha bersama berdasarkan asas kekeluargaan.

Negara Indonesia bercitacita mewujudkan masyarakat yang adil makmur berdasarkan Pancasila dan UUD 1945 harus diwujudkan 
melalui

pembangunan

perekonomian nasional

berdasarkan demokrasi ekonomi.

Wujud pembangunan ekonomi tersebut dapat dilakukan melalui penanaman modal.

Perwujudan masyarakat adil dan makmur berdasarkan Pancasila dan UUD1945 perlu dilaksanakan suatu pembangunan ekonomi nasional yang berkelanjutan dan berlandaskan demokrasi ekonomi untuk mencapai tujuan bernegara. Bahwa dalam menghadapi perubahan perekonomian global dan keiikutsertaan Indonesia dalam berbagai kerjasama internasional perlu diciptakan iklim penanaman modal yang kondusif, promotif, memberikan kepastian hukum, keadilan dan efisien dengan tetap memperhatikan ekonomi nasional.

Pelaksanaan pembangunan di Indonesia memerlukan modal yang cukup besar. Idealnya dari segi nasionalisme pemenuhan akan kebutuhan modal disediakan oleh negara itu sendiri, akan tetapi sebagai negara berkembang masih mengalami keterbatasan modal yang cukup.

Ketersediaan modal dapat segera diatasi dengan cara pemerintah melakukan berbagai kebijakan dan pendekatan kepada negara yang dapat memberikan bantuannya kepada Indonesia. Keberadaan penanaman modal baik Penanaman Modal Dalam Negeri (PMDN) maupun Penanaman Modal Asing (PMA).

Penanaman

Modal

merupakan segala bentuk kegiatan menanam modal, baik oleh penanam modal asing untuk melakukan usaha di wilayah Negara Republik Indonesia.
Kegiatan penanaman modal dalam negeri adalah kegiatan untuk melakukan usaha di wilayah Republik Indonesia yang dilakukan oleh penanam modal dalam negeri menggunakan modal dalam negeri.

Oleh sebab itu penanaman modal harus menjadi bagian dari penyelenggaraan perekonomian nasional dan ditempatkan sebagai upaya untuk meningkatkan pertumbuhan ekonomi nasional, menciptakan lapangan pekerjaan, meningkatkan pembangunan ekonomi meningkatkan kapasitas dan kemampuan teknologi nasional.

Tujuan penyelenggaraan penanaman modal, antara lain untuk: meningkatkan pertumbuhan ekonomi nasional; menciptakan lapangan kerja; meningkatkan pembangunan ekonomi berkelanjutan; meningkatkan kemampuan daya saing dunia usaha nasional; meningkatkan kapasitas dan kemampuan teknologi nasional; mendorong pengembangan ekonomi kerakyatan; mengolah ekonomi potensial menjadi kekuatan ekonomi riil dengan menggunakan dana yang berasal, baik dari dalam negeri maupun dari luar negeri; dan meningkatkan kesejahteraan masyarakat.

\section{Penyelenggaraan}

penanaman dapat tercapai bila faktor penunjang dan penghambat iklim penanaman modal dapat diatasi, melalui perbaikan koordinasi antar-instansi pemerintah pusat dan daerah, penciptaan birokrasi yang efisien, kepastian hukum di bidang penanaman modal, biaya ekonomi yang berdaya saing tinggi, serta ilkim usaha yang kondusif 
dibidang ketenagakerjaan dan keamanan berusaha. ${ }^{9}$

\section{Asas-Asas Hukum}

Penanaman Modal di Indonesia

Asas hukum bukanlah
norma hukum, asas hukum mengandung nilai-nilai moral dan etis. Asas hukum itu mempunyai fungsi (1) pedoman bagi perundang-undangan, (2) dasar dalam melakukan interprestasi, (3) dasar dalam melakukan analogi, dan (4) dasar dalam melakukan koreksi terhadap undang-undang. ${ }^{10}$

Pengaturan penanaman modal di Indonesia diatur dalam Undang-Undang Nomor 25 Tahun 2007 tentang Penanaman Modal. Dalam Undang-Undang Penanaman Modal Pasal 3 dinyatakan bahwa penanaman modal diselenggarakan berdasarkan asas: kepastian hukum; keterbukaan; akuntabilitas; perlakuan yang sama dan tidak membedakan asal negara; kebersamaan; efesiensi berkeadilan; berkelanjutan; berwawasan lingkungan; kemandirian; keseimbangan kemajuan dan kesatuan ekonomi nasional.

\section{a. Asas Kepastian Hukum}

Yang dimaksud dengan asas kepastian hukum adalah asas dalam Negara hukum yang meletakkan hukum dan ketentuan peraturan perundang-undangan sebagai dasar dalam setiap kebijakan dan tindakan dalam bidang investasi.

Asas Kepastian Hukum dalam negara hukum yang

9 Aminuddin Ilmar, Hukum Penanaman Modal di Indonesia, Jakarta: Kencana, 2010, hlm. 64

${ }^{10}$ Indah Febrian, Op. Cit, hlm. 2189-2190 mengutamakan landasan peraturan perundang-undangan, kepatutan, dan keadilan dalam setiap kebijakan Penyelenggara Negara. Kepastian hukum merupakan sebuah jaminan bahwa hukum tersebut harus dijalankan dengan cara yang baik. Kepastian hukum menghendaki adanya upaya pengaturan hukum dalam perundang-undangan yang dibuat oleh pihak yang berwenang dan berwibawa, sehingga aturan-aturan itu memiliki aspek yuridis yang dapat menjamin adanya kepastian bahwa hukum berfungsi sebagai suatu peraturan yang harus ditaati.

Jaminan kepastian hukum berinvestasi menjadi politik hukum Indonesia yang tertuang dalam Undang-Undang Penanaman Modal. Wujudnya dengan adanya kaidah perlindungan dari tindakan nasionalisasi, pemberian kompensasi bila terjadi tindakan nasionalisasi, perlindungan dalam proses penyelesaian sengketa melalui mekanisme musyawarah dan mufakat. ${ }^{11}$

Asas kepastian hukum pada akhirnya harus mencerminkan UUD 1945 sebagai landasan struktur formal hukum positif dan dijiwai oleh falsafah negara Pancasila sebagai cita hukum negara Indonesia. Pancasila merupakan cita hukum Indonesia. Sistem hukum Indonesia anatara lain meliputi struktur formal hukum positif di Indonesia (kaidah-kaidah dan asas-asas) yang berlaku berlandaskan UUD 1945 . $^{12}$

11 Jaja Ahmad Jayus, Konsep Sistem Hukum Investasi dalam Menjamin Adanya Kepastian Hukum, Jurnal Litigasi Vol. 16 No. 2, 2012, hlm. 2935

${ }^{12}$ Mochtar Kusumaatmadja dan B. Arief Sidharta dalam Acep Rohendi, Prinsip Liberalisasi 


\section{b. Asas Keterbukaan}

Yang dimaksud dengan asas keterbukaan adalah asas yang terbuka terhadap hak masyarakat untuk memperoleh informasi yang benar, jujur dan tidak diskriminatif tentang kegiatan investasi.

Keterbukaan merupakan salah satu penggerak perekonomian Indonesia sebagai daya tarik bagi investor-investor dunia. Keterbukaan termasuk faktor yang menggerakkan perekonomian Indonesia agar lebih baik di masa depan.

\section{c. Asas Akuntabilitas}

Yang dimaksud dengan asas akuntabilitas adalah asas yang menentukan bahwa setiap kegiatan dan hasil akhir dari penyelenggaraan investasi harus dipertanggungjawabkan kepada masyarakat atau rakyat sebagai pemegang kedaulatan tertinggi negara sesuai dengan ketentuan peraturan perundang-undangan.

Kepentingan nasional harus diutamakan, adanya kendali negara dalam perlindungan sumber daya alam, perlindungan pengembangan usaha mikro, kecil, menengah dan koperasi, pengawasan produksi dan distribusi, peningkatan kapasitas teknologi, partisipasi modal dalam negeri serta kerjasama dengan badan usaha yang ditunjuk Pemerintah.

d. Asas Perlakuan yang Sama dan Tidak Membedakan Asal Negara

Yang dimaksud dengan asas perlakuan yang sama dan tidak membedakan asal negara adalah

Perdagangan World Trade Organization (WTO) dalam Pembaharuan Hukum Investasi di Indonesia (Undang-Undang Nomor 25 Tahun 2007), Padjajaran Ilmu Hukum, Vol. 1 No. 2 Tahun 2014, hlm. 392 asas perlakuan pelayanan nondiskriminasi berdasarkan ketentuan peraturan perundangundangan, baik antara investor dalam negeri dan investor asing maupun antara investasi dari satu negara asing dan investasi dari negara asing.

Pemerinta memberikan perlakuan yang sama kepada semua penanam modal yang berasal dari negara manapun yang melakukan kegiatan penanaman modal di Indonesia sesuai dengan ketentuan peraturan perundangundangan.

Prinsip non-diskriminasi menekankan pada dasar pemikiran prinsip perlindungan keseimbangan kepentingan antar masing-masing pihak, dengan saling menghormati kedaulatan negara masing-masing dalam menetapkan kebijakan hukum investasinya, saling melindungi dan memberikan perlakuan tanpa diskriminasi antara investor asing dengan investor dalam negeri, juga dengan sesama investor asing.

\section{e. Asas Kebersamaan}

Yang dimaksud dengan asas kebersamaan adalah asas yang mendorong peran seluruh investasi secara bersama-sama dalam kegiatan usahanya untuk mewujudkan kesejahteraan rakyat.

Pengejawantahan dalam

Asas Kebersamaan dengan harus terpenuhinya kriteria-kriteria oleh penanam modal dalam mendapatkan fasilitas. Hal tersebut yakni pada penyerapan banyak

\footnotetext{
${ }^{13}$ Muchammad Zaidun dalam Widhayani Dian, Dialektika Perlindungan Kepentingan Nasional Berdasarkan Konstitusi Ekonomi dengan Basic Principle dalam Bilateral Invesment Treaties, Yuridika FH Universitas Airlangga, Vol. 31 No. 1 Januari 2016, hlm. 147
}

Volume 16 Nomor 3. Bulan September Tahun 2018 
tenaga kerja, melakuakn alih teknologi, melakukan industri pionir bagi daerah terpencil, tertinggal, daerah perbatasan atau daearah yang dianggap perlu. Kebersamaan juga terjalin pada kemitraan dengan usaha mikro, kecil, menengah atau koperasi.

Pemerataan di daerahdaerah dalam kegiataan penanaman modal dilakukan dengan koordinasi pada Badan Koordinasi Penanaman Modal yang mempunyai tugas dan fungsi membuat peta penanaman modal Indonesia, mengembangkan peluang dan potensi penanaman modal di daerah dengan memberdayakan badan usaha.

\section{f. Asas Efisiensi Berkeadilan}

Yang dimaksud dengan asas efisiensi berkeadilan adalah asas yang mendasari pelaksanaan investasi dengan mengedepankan efisiensi berkeadilan dalam usaha untuk mewujudkan iklim usaha yang adil, kondusif dan berdaya saing.

Arah kebijakan penanaman
modal dilakukan dengan
menciptakan iklim investasi dan
iklim usaha yang lebih berdaya
saing, baik di tingkat pusat maupun
daerah, yang dapat meningkatkan
efisiensi proses perijinan,
meningkatkan kepastian
berinvestasi dan berusaha di
indonesia, serta mendorong
persaingan usaha yang lebih sehat
dan berkeadilan.
Dalam rangka mendorong
investasi terkait juga dalam
meningkatkan kapasitas
perekonomian. Pemerintah
memiliki peran besar dalam
menjaga iklim investasi yang
ramah dan kondusif. Pemerintah
mewujudkannya dengan terus
berupaya menjaga stabilitas kondisi

domestik dengan meminimalisir dampak ekonomi global.

\section{g. Asas Berkelanjutan}

Yang dimaksud dengan asas berkelanjutan adalah asas yang secara terencana mengupayakan berjalannya proses pembangunan melalui investasi untuk menjamin kesejahteraan dan kemajuan dalam segala aspek kehidupan, baik untuk masa kini maupun yang akan datang.

$$
\text { Investasi salah satu }
$$

komponen penting dalam pembangunan ekonomi karena mempunyai keterkaitan dengan keberlangsungan kegiatan ekonomi di masa yang akan datang,

\section{h. Asas Berwawasan Lingkungan} Yang dimaksud dengan asas berwawasan lingkungan adalah asas investasi yang dilakukan dengan tetap memerhatikan dan mengutamakan perlindungan dan pemeliharaan lingkungan hidup.

Investasi yang berwawasan lingkungan bertujuan agar investor yang memanfaatkan sumber daya alam tidak merusak lingkungan tersebut. Untuk itu dalam pengelolaan sumber daya alam perlu diperhatikan pada keadaan lingkungan agar ekosistem lingkungan tidak terganggu.

Sumber daya alam merupakan penopang kehidupan penduduk yang perlu dijaga kelestariannya, karena kebutuhan pemenuhan tersebut akan terus berlanjut. Untuk melakukan pembangunan ekonomi melalui investasi dengan memanfaatkan dan mengelola sumber daya alam maka perlu berkolaborasi pada ilmu pengetahuan dan teknologi yang ramah lingkungan dengan tidak merusak ekosistemnya. 


\section{i. Asas Kemandirian}

Yang dimaksud dengan asas kemadirian adalah asas investasi yang dilakukan dengan tetap mengedepankan potensi bangsa dan negara dengan tidak menutup diri pada masuknya modal asing demi terwujudnya pertumbuhan ekonomi.

\section{j. Asas Keseimbangan Kemajuan} dan Kesatuan Ekonomi Nasional

Yang dimaksud dengan asas keseimbangan dan kesatuan ekonomi nasional adalah asas yang berupaya menjaga keseimbangan kemajuan ekonomi wilayah dan kesatuan ekonomi nasional.

Produk

pengaturan perundang-undangan terkait penanaman modal dibuat secara sinergi dan harmonis satu sama lainnya, sehingga tidak terjadi pertentangan dan disharmonis antara peraturan dan kebijakan yang satu dengan lainnya dalam penataan penanaman modal dalam rangka menjaga keseimbangan kepentingan dari pihak-pihak pelaku investasi, pemerintah dan masyarakat. ${ }^{14}$

Kemajuan dan kesatuan ekonomi nasional dalam kehidupan ekonomi adalah kehidupan berbangsa dan bernegara yang bertujuan mewujudkan kesejahteraan rakyat dalam keadilan sosial, sebagaimana yang dicita-citakan Pancasila. ${ }^{15}$

\section{III.PENUTUP}

\section{Dari}

sebelumnya maka dapat
14 Saut P. Panjaitan, Teori-Teori Penanaman Modal Asing dan Kaitannya dengan Aspek Teori Hukum, Jurnal Hukum Prodi Ilmu Hukum Pascasarjana Unsri, Vol. VI No. 2 Juni 2008, hlm. 63

${ }^{15}$ Sri Redjeki Hartono, Hukum Ekonomi Indonesia, Malang: Banyumedia, 2007, hlm. 31 disimpulkan bahwa Pancasila sebagai landasan filosofis bangsa Indonesia berpengaruh dalam pembangunan perekonomian bangsa Indonesia melalui kegiatan penanaman modal baik penanaman modal dalam negeri maupun penanaman modal asing.

Pengaturan penanaman modal di Indonesia yang diatur dalam Undang-Undang Nomor 25 Tahun 2007 tentang Penanaman Modal, bahwa penanaman modal diselenggarakan berdasarkan asas: kepastian hukum; keterbukaan; akuntabilitas; perlakuan yang sama dan tidak membedakan asal negara; kebersamaan; efesiensi berkeadilan; berkelanjutan; berwawasan lingkungan; kemandirian; keseimbangan kemajuan dan kesatuan ekonomi nasional.

\section{DAFTAR PUSTAKA}

\section{A. Buku}

Aminuddin Ilmar, Hukum Penanaman Modal di Indonesia, Jakarta: Kencana, 2010.

Elsi Kartika Sari dan Advendi Simanunsong, Hukum dalam Ekonomi, Jakarta: PT Gramedia Widiasarana Indonesia, 2008.

Noeng Muhadjir, Filsafat Ilmu, Yogyakarta: Rake Sarasin, 2015.

Peter Machmud Marzuki, Penelitian Hukum, Jakarta: Kencana Prenada Media Group, 2009.

Soeprapto, Pancasila, Jakarta: Konstitusi Press, 2013.

Sri Redjeki Hartono, Hukum Ekonomi Indonesia, Malang: Banyumedia, 2007.

\section{B. Jurnal}

Acep Rohendi, Prinsip Liberalisasi Perdagangan World Trade Organization (WTO) dalam Pembaharuan Hukum Investasi di 
Ardiana Hidayah, Landasan Filosofis Dan Asas-Asas Dalam Hukum Penanaman Modal Di Indonesia

Halaman 216-226

Indonesia (Undang-Undang

Nomor 25 Tahun 2007), Padjajaran Ilmu Hukum, Vol. 1 No. 2 Tahun 2014.

Indah Febrian, Aspek Filosofis dalam Hukum Ekonomi, Simbur Cahaya No. 43 Tahun XV, September 2010.

Jaja Ahmad Jayus, Konsep Sistem Hukum Investasi dalam Menjamin Adanya Kepastian Hukum, Jurnal Litigasi Vol. 16 No. 2, 2012.

Saut P. Panjaitan, Teori-Teori Penanaman Modal Asing dan Kaitannya dengan Aspek Teori Hukum, Jurnal Hukum Prodi Ilmu Hukum Pascasarjana Unsri, Vol. VI No. 2 Juni 2008.

Widhayani Dian, Dialektika Perlindungan Kepentingan Nasional Berdasarkan Konstitusi Ekonomi dengan Basic Principle dalam Bilateral Invesment Treaties, Yuridika FH Universitas Airlangga, Vol. 31 No. 1 Januari 2016.

\section{Perundang-undangan}

Undang-Undang Dasar Negara Republik Indonesia Tahun 1945

Undang-Undang Nomor 25 Tahun 2007 tentang Penanaman Modal 